\title{
Role of Microfinance in Poverty Alleviation: Evidence from Pakistan
}

\author{
Abdul Ghafoor Awan $^{1 *}$, Muhammad Javed Iqbal Juiya ${ }^{2}$ \\ ${ }^{1}$ Dean, Faculty of Management and Social Sciences, Institute of Southern Punjab, Multan, PAKISTAN \\ ${ }^{2}$ M. Phil Scholar, Department of Economics, Institute of Southern Punjab, Multan, PAKISTAN \\ *E-mail for correspondence: ghafoor70@yahoo.com \\ Cell Phone: +0923136015051
}

Received: Jun 18, 2015;

Accepted: Jul 2, 2015;

Published: Jul 21, 2015

Source of Support: Nil

No Conflict of Interest: Declared

\begin{abstract}
This study has empirically measured the role of microfinance in poverty alleviation and has examined its impact on household poverty level. The factors that can affect the household poverty and living standard have been investigated with innovative econometric technique that is binary logit model and ordered logit model by using Stata software. The empirical analysis of this study is based on fresh data. The data is collected through a household survey method from the rural and urban areas of district Lodhran of Pakistan. A questionnaire was developed to collect primary data which covered the household loan amount, household assets, and household expenditures. The questionnaires were distributed among 220 respondents. We selected total 19 variables: eleven variables to analyze the factors responsible for household poverty and eight variables to measure the household living standard. High value of Living standard shows high living standard and low value shows lower living standard. The empirical evidence shows that the variables such as gender, married status, chronicle diseases, purpose of loans, number of loans taken, amount of loan, Lives Stock, Monthly savings, total number of household members are found impacting poverty significantly while the impact of transport facility, years of schooling and ownership of land were found insignificant. While measuring poverty level we followed World Bank poverty line which is \$ 1.25 (Rs.3750) per capita per adult monthly income and expenditure. The data shows that 137 (62.3 percent) households are living below poverty line while 83 households are living above poverty line. We find that 169 households (76.8 percent of the total sample) have good living standard while 20 households (9.1 percent) have high living standard whereas 31 households (14.1 percent), have very low living standard.
\end{abstract}

Keywords: microfinance, availability of loan, gender, monthly saving, marital status, poverty, alleviation

JEL Classifications Code: E6

\section{INTRODUCTION}

\section{What is Microfinance?}

According to Otero (1999) "Microfinance is the provision of financial services to low-income and self-employed people." These financial services generally include savings and credit but can also include other financial services such as insurance and payment services. Schreiner and Colombet (2001) define microfinance as "the attempt to improve access to small deposits and small loans for poor households neglected by banks." Therefore, microfinance include the prerequisite of financial services such as savings, loans and insurance to poor people living in both urban and rural areas who are incapable to obtain such services from the formal financial sector. Awan et al (2015) maintain that microfinance is the lifeblood of small medium enterprises and as they play a significant role in the alleviation of poverty. Awan \& Gilani (2014) argue that financial institutions' role in alleviation of poverty particularly in backward areas of underdeveloped countries is vital. Awan \& Maleeha (2014) state that expansion of microfinance services in the rural areas are necessary for eradication of poverty and inequality.

\section{What is Poverty?}

According to the Economic Survey of Pakistan 2013-2014, poverty is defined as "a state or condition in which a person or community lacks the financial resources and essential goods and services to enjoy a minimum standard of life and well-being that's considered acceptable in society". Awan (2015) pleads that povertyis deprivation having many dimensions. It includes low incomes and the inability of the 
people to acquire basic goods and services necessary for survival. We can see that income inequality in the world is astonishing as 94 percent of the world income is earned by $40 \%$ of the total world population whereas $61 \%$ of world population is earning only 6 percent of world income. About half of the total world population earns only two dollars per day and over one billion people earns only less than a dollar per day. The UN's Economic and Social Council (2009) has described poverty as:

"... A denial of choices and opportunities, a violation of human dignity. It means lack of basic capacity to participate effectively in society. It means not having enough to feed and clothe a family, not having a school or clinic to go to, not having the land on which to grow one's food or a job to earn one's living, not having access to credit. It means insecurity, powerlessness, and exclusion of individuals, households, and communities. It means susceptibility to violence, and it often implies living on marginal or fragile environments, without access to clean water orsanitation"

The Economic Survey of Pakistan (2014) states that if the poverty line is taken as $\$ 2$ per day in line with international standards for middle-income countries, then 60.19 percent of the population fall below poverty line in Pakistan. However, if income per adult in Pakistan is taken as \$ 1.25 per day, then 21.04 percent of the population falls below poverty line. Awan (2015) emphasized that the situation of poverty in Pakistan is better to some extent as compared to India and Bangladesh but Sri Lanka, China and Philippine's are in a better position than Pakistan. The percentage of population below \$2 per day in China is 29.79 percent; Bangladesh 76.54 percent, Indian 68.72 percent, Sri Lanka 29.13 percent, Nepal 57.25 percent, and Philippines 41.53 percent. As per 2014 data, per capita income in Pakistan in dollar terms has reached to $\$ 1,386$.

\section{Main Research Question}

Our main research question is the "Role of microfinance in Poverty Alleviation: A Case Study of District LodhranPakistan"

\section{Objective of Study}

The objectives of our study are stated as under:-

- To evaluate the impact of microfinance on poverty alleviation of Households.

- To evaluate the impact of microfinance on Living Standard of Households

- To provide the appropriate measure for the effective use of microfinance.

\section{Research Methodology}

\section{Main Focus of study}

Our study has mainly focused on an interest free loan given by Akhuwat which is a microfinance Bank established in 2001 in Pakistan. At initial stage it was a small financial institution but now it has grown to a big one in Pakistan. Akhuwat derived motivation from the Muslim spirit of Muakhaat (or Brotherhood). The original example of Muakhaat was first displayed by the people of
Madina at the dawn of Islam, when they decided to share their assets with the immigrants or Muhajirin of Mecca. Akhuwat philosophy of giving loan is being built by its pioneers on the principle of Qarze-e-Hasna, meaning to help someone during financial crisis by giving interestfree loans. Akhuwat started with Rs.10, 000/- loan to each borrower 14 years back which has no has crossed to PK Rupees $12,913,673,842$ by January 31, 2015. The number of branches has reached 342 while numbers of borrowers have exceeded 761,858 across Pakistan. Surprisingly, the loan recovery rate is 99.87 percent. It is important to mention that the entire loan are disbursed and recovered in Mosques. Mosque is assumed to be a holy place and nobody can expect that anyone who makes any commitment in the mosque will dare to denial. This is the main reason low rate of default. Awan \& Maleeha (2014) says that consumers' commitment with Islamic financial institutions is growing in Pakistan due to better services and loans provision on the basis of profit and loss.

\section{Data and Sample}

Our empirical analysis is based on primary data collected through a structured questionnaire. The sample size of this study was 220. The collected data containinformation regarding house, business, expenditure, and assets of the households.

\section{Poverty Measuring Scale}

The poverty line is taken from Pakistan Economic Survey 2013-2014. This poverty line is given by World banks Poverty Head Count Analysis 2014. In this analysis \$ 1.25 per day per adult is supposed as a poverty line.

\section{Household Poverty}

In current study the household whose per capita income per month is below the poverty line considered poor and are assigned value one and household whose per capita income is above the poverty line is considered as nonpoor and assigned value 0 .

\section{Types OF ECONOMETRIC MOdELS}

We have developed three separate econometric models. The first model depicts the households' poverty level; the second model shows the household expenditures, and third model deals with household living standard.

\section{Household poverty level Model}

In our analysis we have taken different variables that show the living standard of a household. We have given value to the household according to the availability of those goods and services. The order of Living Standard lies between 1-3.The maximum values for best living standard is 12 . We have given value 1 to those household who ranges between 1-6, 2, 7-10 and, 3 who ranges between 10-12. The first model is engraved as

$\mathrm{Po}=\mathrm{f}$ (Gend, M_S, TNHM, C_Dises, POL, NoTLT, AOL, L_Stock, Msav, ASTF) 
Household Poverty $=\beta$ o $-\beta_{1}$ Gend $+\beta_{2}$ M $S+\beta_{3}$ TNHM + $\beta_{4}$ C_Dises $+\beta_{5}$ POL - $\beta_{6}$ NoTLT - $\beta_{7}$ AOL - $\beta_{8}$ L_Stock $\beta_{9}$ Msav $-\beta_{10} \mathrm{ATF}+\mu$

Where

$\beta_{0}=$ Intercept

$\beta 1, \beta 2, \beta 3, \beta 4 \beta 5, \beta 6, \beta 7, \beta 8, \beta 9, \beta 10=$ the slope coefficient

of independent variables

$\mu=$ the stochastic error term

Po $=1$ if household is poor

$\mathrm{Po}=0$ if household is non poor

Household poverty =incidence of household poverty measured at World Bank given poverty line

Gender $=$ Male or Female

M_S = Marital Status

TNHM $=$ Total Number of Household Members

C_Dises $=$ Chronical Diseases

POL = Purpose of Loan Taken

NoTLT $=$ Number of Time Loan Taken

ALT = amount of loan taken

L Stock = Live Stock

Msav.= Monthly Saving

ATF = Availability of Transportation Facility

\section{Explanation of Variables}

Gender of Household

It plays very important role in eradication of poverty. It has negative relationship with household poverty. As our society is male dominant male usually have more working opportunities as compared to female. We have taken gender as binary variable by giving 1 to male and 0 to female.

\section{Marital Status of Household}

We have taken marital status as an independent variable. Marital status has negative relationship with household poverty because if both family members earns they can draw their family out of poverty. We have taken marital status as binary variable by giving 1 to married and o to non-married.

Total Number of Household

It means household size. It has positive relationship with poverty as poverty will increase with the increase in total number of household members. We have taken it as continue variable. It is measured by calculating the total family members to that household.

\section{Number of time loan taken}

A household who take more time loans shows that he is expanding his business and in return he will be able to earn money to help his family to come out from poverty. Theoretically number of time loan taken has negative effect on poverty as people who take more time loan have the chance to lessen the poverty. It is a continuous variable

\section{Saving of Household}

It has negative relationship with poverty. We have taken it as binary variable and have given 1 if saving yes or 0 if saving no. usually a household save income to invest it into the business or to purchase assets which can contribute to their income level.

\section{Availability of Transportation facility}

In this modern age transportation facility has become as a basic need for everyone because it saves our time andtoday time is money. We have taken it as binary variable and have given 1 if yes and 0 if no. it has negative relationship with poverty because the transportation facility help the households in many ways, for example, households can bring luggages and other items from remote areas to his shops. They can also pick and drop their children from school.

\section{Chronic disease}

If A household have any chronic disease he will not be able to maintain his daily expenditure as major amount of earning will be spent on treatment. It has positive relationship with poverty. We have taken it as binary variable the presence of chronic disease is valued 1 and absent with value 0 .

\section{Objective of loans}

A household take loans for two purposes, either to start business and to expand it. We have taken it as binary variable by giving 1 to expand the business and o to start the business.

\section{Livestock}

As our survey covers the both urban and rural areas, mostly in in rural areas people like to have livestocks for multiple purposes as they fulfill their daily milk demand but also they can slaughter them for meat.

\section{Amount of loan}

We have taken amount of loan taken as independent variable. It is continuous variable. Amount of loan has negative relationship with poverty. As the amount of loan taken increases household have greater opportunity to invest it in a good business.

\section{Household per capita consumption Model}

We have also constructed a household consumption model to measure poverty level. Usually in developing countries people give more reliable information about their consumption. Poverty level is based on expenditures on consumer items in most of the developing countries. As poverty yardstick is Rs.3750 (\$1.25) per capita income we assume that household spends all their income on consumption. We have taken Household expenditure as binary variable. Household with less than given amount is taken as poor with value 0 and household with value 1 as non-poor. We have drawn our model in the following equation:-

Po $=$ f (Gend, Edu, YS, TNHM, C_Dises, NoTLT, OSL, AOL, Msav, ATF)

Household Expenditure $=\beta \mathrm{o}-\beta_{1}$ Gend $-\beta_{2}$ Edu $+\beta_{3}$

$\mathrm{TNHM}+\beta_{4} \mathrm{C}_{-}$Dises $+\beta_{5} \mathrm{YS}+\beta_{6} \mathrm{NoTLT}_{-}+\beta_{7}$ AOL $+\beta_{8}$ OSL $\beta_{9}$ Msav $+\beta_{10}$ ATF $+\mu$

Where

$\beta_{0}=$ Intercept

$\beta 1, \beta 2, \beta 3, \beta 4 \beta 5, \beta 6, \beta 7, \beta 8, \beta 9, \beta 10=$ the slope coefficient of independent variables 
$\boldsymbol{\mu}=$ the stochastic error term

$\mathrm{Po}=1$ if household is poor

Po $=0$ if household is non poor

Household poverty $=$ incidence of household poverty as per World Bank criteria.

Gender $=$ Male or Female

Edu. = Literate or illiterate

TNHM $=$ Total Number of Household Members

C_Dises $=$ Chronic Diseases

YS $\quad=$ Years of Schooling

NoTLT $=$ Number of Time Loan Taken

Ownership of land = Live Stock

Msav = Monthly Saving

ATF = Availability of Transportation Facility

\section{Household Living Standard Model}

In this Model we have taken household living standard as dependent variable and regress it on different independent variable to assess the conditions of household living standard. We have ordered the living standard from 1 to 3 . One shows lowest living standard, 2 modest and 3 good. As the data is in ordered form therefore we will use "Ordered Logistic" regression technique. We have shown model 3 as under:-

Living Standard = f (YS, SGC, NoTLT, OSL, L_Stock, Msav, support ratio, automob)

Household Living Standard $=\beta 0-\beta_{1}$ YS $-\beta_{2}$ SGC + $\beta_{3}$ NoTLT $+\beta_{4}$ OSL $+\beta_{5}$ L_Stock $+\beta_{6}$ Msav $+\beta_{7}$ supportratio $+\beta_{8} \mathrm{~A}+\mu$

Where

$\beta_{0}=$ Intercept

$\beta 1, \beta 2, \beta 3, \beta 4 \beta 5, \beta 6, \beta 7=$ the slope coefficient of

independent variables

$\boldsymbol{\mu}=$ the stochastic error term

$P_{0}=1$ if household living standard is very low

$P_{0}=2$ if household living standard is good

$P_{O}=3$ if household living standard is high.

YS = Years of Schooling

SGC $=$ Number of school going children

NoTLT $=$ Number of time loan taken

OSL $=$ Ownership of land

L_Stock = Availability of live stock

Msav = Monthly saving

Suportro.= Support ratio

ATF $=$ Availability of Transportation Facility

\section{DescriptiVe ANALYSIS}

Poverty level in District Lodhran is determined by using the World Bank poverty line \$ 1.25 (RS.3750) per capita income. The household having per capita income below this poverty line is considered as poor and is assigned value " 1 " otherwise " 0 ." This research study tries to analyze the factors contributing positively or negatively to the poverty level and living Standard of the target group of households.
Table 1 Incidence of household poverty in Sample

\begin{tabular}{|l|c|c|}
\hline Po & Frequency & Marginal Percentage \\
\hline Non-Poor 0 & 83 & $37.7 \%$ \\
\hline Poor 1 & 137 & $62.3 \%$ \\
\hline Total & 220 & $100 \%$ \\
\hline
\end{tabular}

Data given in the above table shows that 137 out of total 220 household are found below Poverty line. It shows that 62.3 percent of household are poor in the study area while 83 are foundnon-poor or above the poverty line which depicts $37.7 \%$ of targetted households.

Table 2 Incidence of Living Standard inthe sample group

\begin{tabular}{|l|l|l|}
\hline Po & Frequency & $\%$ \\
\hline Low living standard & 31 & $14.1 \%$ \\
\hline Moderate living standard 2 & 169 & $76.8 \%$ \\
\hline High living standard 3 & 20 & $9.1 \%$ \\
\hline Total & 220 & $100 \%$ \\
\hline
\end{tabular}

In the Table 2 we have determined living standard by adding nine indicator which make total score of 12 . We give 1 to that household who got 6 score out of total 12,2 to that household who got value between 7 to 10 and 3 to that household who got score between 10-12. 1 shows lowest living standard, 2 shows moderate living standard and 3 shows high living standard. In the analysis it is found that $14.1 \%$ of household have low level of living standard, $76.8 \%$ household have moderate living standard and 9.1\% household have high level standard.

Table 3 Gender of the head of the household and incidence of poverty

\begin{tabular}{|c|c|c|c|c|c|c|}
\hline Po & \multicolumn{2}{|c|}{ Poor (Po,1) } & \multicolumn{2}{c|}{ Non Poor (Po,0) } & \multicolumn{2}{l|}{ Total } \\
\hline $\begin{array}{c}\text { Gender } \\
\text { of the } \\
\text { household }\end{array}$ & Frequency & $\%$ & Frequency & Frequency & Frequency & $\%$ \\
\hline Female & 25 & $\begin{array}{l}18.2 \% \\
73.5 \%\end{array}$ & 9 & $\begin{array}{l}10.8 \% \\
26.5 \%\end{array}$ & 34 & $15.5 \%$ \\
\hline Male & 112 & $\begin{array}{l}81.8 \% \\
60.2 \%\end{array}$ & 74 & $\begin{array}{l}89.2 \% \\
39.8 \%\end{array}$ & 186 & $84.5 \%$ \\
\hline Total & 137 & & 83 & & 220 & $100 \%$ \\
\hline
\end{tabular}

Table 3 depicts that 15.5 percent of total poor and nonpoor are female and 84.5 percent of total poor and nonpoor are male.

Table 4 Education of the head of the household and incidence of poverty

\begin{tabular}{|c|c|c|c|c|c|c|}
\hline Po & \multicolumn{2}{|c|}{ Poor(Po,1) } & \multicolumn{2}{c|}{ Non Poor (Po,0) } & \multicolumn{2}{c|}{ Total } \\
\hline $\begin{array}{c}\text { Education } \\
\text { of the } \\
\text { household }\end{array}$ & Frequency & $\%$ & Frequency & Frequency & Frequency & $\%$ \\
\hline Female & 34 & $\begin{array}{r}24.8 \% \\
68.0 \%\end{array}$ & 16 & $\begin{array}{c}19.3 \% \\
32.0 \%\end{array}$ & 50 & $22.7 \%$ \\
\hline Male & 103 & $\begin{array}{l}75.2 \% \\
60.6 \%\end{array}$ & 67 & $\begin{array}{l}80.7 \% \\
39.4 \%\end{array}$ & 170 & $77.3 \%$ \\
\hline Total & 137 & & 83 & & 220 & $100 \%$ \\
\hline
\end{tabular}

Table 4shows that 22.7 percent of the total female is literate out of which 16 female are non-poor and 34 are poor. The table also shows that 77.3 percent male are literate out of which 67 are non-poor and 103 are poor. 
Table 5 Years of schooling of the head of the household and incidence of poverty

\begin{tabular}{|c|c|c|c|c|c|c|}
\hline Po & \multicolumn{2}{|c|}{ Poor $(\mathrm{Po}, 1)$} & \multicolumn{2}{|c|}{ Non Poor $(\mathrm{Po}, 0)$} & \multicolumn{2}{|c|}{ Total } \\
\hline $\begin{array}{l}\text { Education of } \\
\text { the household }\end{array}$ & Frequency & $\%$ & Frequency & $\%$ & Frequency & $\%$ \\
\hline Illiterate & 35 & $\begin{array}{l}25.5 \% \\
68.6 \%\end{array}$ & 16 & $\begin{array}{l}19.3 \% \\
31.4 \%\end{array}$ & 51 & $23.2 \%$ \\
\hline Primary & 67 & $\begin{array}{l}48.9 \% \\
59.8 \%\end{array}$ & 45 & $\begin{array}{l}54.2 \% \\
40.2 \%\end{array}$ & 112 & $50.9 \%$ \\
\hline Secondary & 28 & $\begin{array}{l}20.4 \% \\
60.9 \%\end{array}$ & 18 & $\begin{array}{l}21.7 \% \\
39.1 \%\end{array}$ & 46 & $20.9 \%$ \\
\hline Higher & 7 & $\begin{array}{l}5.1 \% \\
63.6 \%\end{array}$ & 4 & $\begin{array}{c}4.8 \% \\
36.4 \%\end{array}$ & 11 & $5.0 \%$ \\
\hline Total & 137 & & 83 & & 220 & $100.0 \%$ \\
\hline
\end{tabular}

The table 5 shows the years of schooling of the head of the households. It shows that 23.2 percent total poor and non-poor are illiterate whereas 50.9 percent are of total household head poor and non-poor have primary education out of which 40.2 percent arenon-poor and 59.8 percent are poor.20.9 percent of poor and non-poor have secondary education. Only 5 percent poor and non-poor have higher education.

Table 6 Total number of school going children of the head of the household and incidence of poverty

\begin{tabular}{|c|c|c|c|c|c|c|}
\hline Po & \multicolumn{2}{|c|}{ Poor(Po,1) } & \multicolumn{2}{c|}{ Non Poor (Po,0) } & \multicolumn{2}{|c|}{ Total } \\
\hline SGC & Frequency & $\%$ & Frequency & $\%$ & Frequency & $\%$ \\
\hline 0 & 30 & $21.9 \%$ & 61 & $73.5 \%$ & 91 & $41.4 \%$ \\
& & $33.0 \%$ & & $67.0 \%$ & & \\
\hline $1-5$ & 96 & $70.1 \%$ & 21 & $25.3 \%$ & 117 & $53.2 \%$ \\
& & $82.1 \%$ & & $17.9 \%$ & & \\
\hline $6-10$ & 11 & $8.0 \%$ & 1 & $1.2 \%$ & 12 & $5.5 \%$ \\
& & $91.7 \%$ & & $8.3 \%$ & & \\
\hline Total & 137 & & 83 & & 220 & $100.0 \%$ \\
\hline
\end{tabular}

Table 6 explains that 53.2 percent of the total households send their children to school between the numbers 1-5. Whereas 5.5 percent of the total households send their children between 6 and 10. It means that the households whose number of children going to school 1-5 are greater in which 96 are poor household child and 21 are non-poor household child out of 220 sampling populations.

Table 7 Total income of the head of the household and incidence of poverty

\begin{tabular}{|c|c|c|c|c|c|c|}
\hline Po & \multicolumn{2}{|c|}{ Poor $($ Po, 1$)$} & \multicolumn{2}{|c|}{ Non Poor $(\mathrm{Po}, 0)$} & \multicolumn{2}{|c|}{ Total } \\
\hline $\mathrm{HY}$ & Frequency & $\%$ & Frequency & $\%$ & Frequency & $\%$ \\
\hline 1 & 68 & $\begin{array}{l}49.6 \% \\
72.3 \%\end{array}$ & 26 & $\begin{array}{l}31.3 \% \\
27.7 \%\end{array}$ & 94 & $42.7 \%$ \\
\hline 2 & 69 & $\begin{array}{l}50.4 \% \\
56.1 \%\end{array}$ & 54 & $\begin{array}{l}65.1 \% \\
43.9 \%\end{array}$ & 123 & $55.9 \%$ \\
\hline 3 & 0 & $\begin{array}{l}0.0 \% \\
0.0 \%\end{array}$ & 3 & \begin{tabular}{|c|}
$3.6 \%$ \\
$100.0 \%$
\end{tabular} & 3 & $1.4 \%$ \\
\hline Total & 137 & & 83 & & 220 & $100.0 \%$ \\
\hline
\end{tabular}

The data of Table 7 shows that 55.9 percent of selected households lay between the groups 2 that ranging Rs.16000-Rs.25000, out of whom 123 households are non-poor and 69 poor.

Table 8 Total number of household members of the head of the household and incidence of poverty

\begin{tabular}{|c|c|c|c|c|c|c|}
\hline Po & \multicolumn{2}{|c|}{ Poor(Po,1) } & Non Poor (Po,0) & \multicolumn{2}{c|}{ Total } \\
\hline $\begin{array}{c}\text { Total number of } \\
\text { Household members }\end{array}$ & Frequency & $\%$ & Frequency & $\%$ & Frequency & $\%$ \\
\hline 1 & 31 & $\begin{array}{l}22.6 \% \\
28.2 \%\end{array}$ & 79 & $\begin{array}{r}95.2 \% \\
71.8 \%\end{array}$ & 110 & $50.0 \%$ \\
\hline 2 & 99 & $\begin{array}{c}72.3 \% \\
96.1 \%\end{array}$ & 4 & $\begin{array}{c}4.8 \% \\
3.9 \%\end{array}$ & 103 & $46.8 \%$ \\
\hline 3 & 7 & $5.1 \%$ & 0 & $\begin{array}{c}0.0 \% \\
0.0 \%\end{array}$ & 7 & $3.2 \%$ \\
\hline Total & 137 & & 83 & & 220 & $100.0 \%$ \\
\hline
\end{tabular}

Table 8 shows that $50 \%$ of households( poor and non-poor) has family size 1-5. It is also average family size and out of which 79 are non-poor and 31 are poor. Whereas $46.8 \%$ percent household grade 2 out of which 4 are non-poor and 99 are poor.

Table 9 Monthly Saving of household and incidence of poverty

\begin{tabular}{|c|c|c|c|c|c|c|}
\hline Po & \multicolumn{2}{|c|}{ Poor (po,1) } & \multicolumn{2}{c|}{ Non poor $(\mathrm{po}, 0)$} & \multicolumn{2}{c|}{ Total } \\
\hline Msav. & Frequency & $\%$ & Frequency & $\%$ & Frequency & $\%$ \\
\hline 1 & 46 & $\begin{array}{c}33.6 \% \\
83.6 \%\end{array}$ & 9 & $\begin{array}{r}10.8 \% \\
16.4 \%\end{array}$ & 55 & $25.0 \%$ \\
\hline 2 & 77 & $\begin{array}{r}56.2 \% \\
58.8 \%\end{array}$ & 54 & $\begin{array}{r}65.1 \% \\
41.2 \%\end{array}$ & 131 & $59.5 \%$ \\
\hline 3 & 12 & $\begin{array}{c}8.8 \% \\
42.9 \%\end{array}$ & 16 & $\begin{array}{r}19.3 \% \\
57.1 \%\end{array}$ & 28 & $12.7 \%$ \\
\hline 4 & 2 & $\begin{array}{c}1.5 \% \\
33.3 \%\end{array}$ & 4 & $\begin{array}{c}4.8 \% \\
66.7 \%\end{array}$ & 6 & $2.7 \%$ \\
\hline Total & 137 & & 83 & & 220 & $100.0 \%$ \\
\hline
\end{tabular}

Table 9 give us average of monthly saving amount of sampling group of households. Around 59.5 percent of selected households saves between Rs. 1000- to Rs.5000 and are assigned grade 2 in which 54 are non-poor and 77 are poor. 25 percent of total poor and non-poor do not save and have grade 1.

Table 10 Marital status of household and incidence of poverty

\begin{tabular}{|c|c|c|c|c|c|c|}
\hline Po & \multicolumn{2}{|c|}{ Poor (po,1) } & \multicolumn{2}{|c|}{ Non poor (po,0) } & \multicolumn{2}{|c|}{ Total } \\
\hline MGB & Frequency & $\%$ & Frequency & $\%$ & Frequency & $\%$ \\
\hline 0 & 11 & $\begin{array}{c}8.0 \% \\
44.0 \%\end{array}$ & 14 & $\begin{array}{r}16.9 \% \\
56.0 \%\end{array}$ & 25 & $11.4 \%$ \\
\hline 1 & 126 & $\begin{array}{r}92.0 \% \\
64.6 \%\end{array}$ & 69 & $\begin{array}{l}83.1 \% \\
35.4 \%\end{array}$ & 195 & $88.6 \%$ \\
\hline Total & 137 & & 83 & & & $100 \%$ \\
\hline
\end{tabular}

Table10 gives us information about the marital status of the poor and non-poor households. It shows that 88.6 percent of the poor and non-poor are married in which household belongs to poor category are 126 and non-poor category are 69. It means the mature and responsible household are getting loan to support their families.

Table 11 Total Number of time Loan taken of household and incidence of poverty

\begin{tabular}{|lc|c|c|c|c|c|c|}
\hline \multicolumn{2}{|c|}{ Po } & \multicolumn{2}{|c|}{ Poor (po,1) } & \multicolumn{2}{c|}{ Non poor $(\mathrm{po}, 0)$} & \multicolumn{2}{c|}{ Total } \\
\hline \multicolumn{2}{|c|}{ TNTLT } & Frequency & $\%$ & Frequency & $\%$ & Frequency & $\%$ \\
\hline 1 & 4 & 71 & $\begin{array}{l}51.8 \% \\
61.2 \%\end{array}$ & 45 & $\begin{array}{l}54.2 \% \\
38.8 \%\end{array}$ & 116 & $52.7 \%$ \\
\hline 2 & 8 & 66 & $\begin{array}{l}48.2 \% \\
63.5 \%\end{array}$ & 38 & $\begin{array}{l}45.8 \% \\
36.5 \%\end{array}$ & 104 & $47.3 \%$ \\
\hline \multicolumn{2}{|c|}{ Total } & 137 & & 83 & & 220 & $100 \%$ \\
\hline
\end{tabular}

Table 11 explains number of time loan taken by selected households. The average shows that 52.7 percent of the household poor and non-poor avail the loan for 1-4 and falls in grade 1.Among them 45 are non-poor and 71 are poor..47.3 percent poor and non-poor household took the loan 5-8 times and falls in grade 2 .

Table 12 Availability of transpiration facility household and incidence of poverty

\begin{tabular}{|c|c|c|c|c|c|c|}
\hline Po & \multicolumn{2}{|c|}{ Poor (po,1) } & \multicolumn{2}{c|}{ Non poor $(\mathrm{po}, 0)$} & \multicolumn{2}{c|}{ Total } \\
\hline ATF & Frequency & $\%$ & Frequency & $\%$ & Frequency & $\%$ \\
\hline 0 & 53 & & 34 & & 87 & $39.5 \%$ \\
\hline 1 & 20 & & 9 & & 29 & $13.2 \%$ \\
\hline 2 & 64 & & 40 & & 104 & $47.3 \%$ \\
\hline Total & 137 & & 83 & & 220 & $100 \%$ \\
\hline
\end{tabular}


Table 12 tells us about the availability of the transport facility to the households. We assign 0 to those households having no transport facility while 1 to those having bicycle and 2 having motorcycle. The result indicates that 47.3 percent of total poor and non-poor category household got the grade 2 and 13.2 percent of total poor and non-poor category household got grade 1 while the remaining got grade 0 .

\section{FINDINGS AND RESULTS}

\section{Measuring household poverty level}

We used Binary Logistic Model to measure the household poverty level. A person living below poverty line has been taken as poor with value 1 and a person above poverty line has been taken as non-poorwith value 0 . We have to explore the determinants of household poverty in term of their per capita income and per capita consumption and living standard through wealth index.Gender,Marital status, total number of household members, any person with chronic diseases, purpose of loan taken, number of time loan taken, amount of loan taken, livestock, monthly saving and possession of satisfactory transportation facility are taken as explanatory variables. The results of binary logistic model are shown in table 13.

Table 13 Regression analysis of households' per capita consumption

\begin{tabular}{|l|l|c|}
\hline Variables & $\beta$ & Level of Significance \\
\hline Gend & -1.514 & 0.067 \\
\hline Edu & -2.109 & 0.071 \\
\hline YS & .114 & 0.300 \\
\hline TNHM & 1.923 & 0.000 \\
\hline C_Dises & -1.146 & 0.070 \\
\hline NoTLT & -.529 & 0.018 \\
\hline OSL & 1.823 & 0.273 \\
\hline AOL & -1.003 & 0.063 \\
\hline Msav & -3.495 & 0.000 \\
\hline ATF & -.516 & 0.362 \\
\hline Constant & .446 & 0.784 \\
\hline Pseudo R2 & \multicolumn{3}{|c|}{$=0.6480$} \\
\hline LR chi2(10) & $=164.47$ \\
\hline DF $=10$ \\
\hline Prob> chi2 & $=0.0000$ \\
\hline Population & $=220$ \\
\hline
\end{tabular}

Incidence of poverty as dependent variable

\section{Measuring household poverty and per capita consumption}

Binary Logistic regression analysis is also applied here to measure the effect of different variables on household poverty with respect to per capita consumption.

Gender and Household poverty: The result is statistically significant showing the probability of household poverty is reduced as the family member is male. As we know men have better foresight than women so there is possibility that a male member will save more money for future. The result is similar with Qureshi et al (2012).

Education and Household poverty: The result is statistically significant showing the probability of household poverty to be decreased as education level increases because a literate person can judge the things far better than an illiterate person. This result is also similar with Qureshi et al (2012), Electrin et al (2013) and Adjei et al (2009).

Total number of household members and Household poverty: The relationship between the variables is statistically significant at 1 percent level of significance and the sign is positive. In other words the probability of household poverty increases as number of household member's increased. The result is similar with Enisan (2012).

Chronic Diseases and Household poverty: The result of chronic diseases with respect to household poverty is astonishing that is negative. It shows the probability of household poverty to be decreased as the chronic disease increases.

Number of times loan taken and Household poverty: The findings show a negative relationship between both. The result is statistically significant. The probability of household poverty is reduced as number of time loan taken is increased.

Amount of Loan Taken and Household poverty: This result is statistically significant showing that the probability of household poverty is reduced as the amount of loan taken is increased because more loan amount means more money to be invested in business to expand and earn more for further reinvestment resulting in the decrease of poverty level.

Saving and household poverty: the probability of household poverty is reduced as saving increases because a household save more for child education, marriage, and business purposes. Due to these reasons households poverty decreases as their saving increases. This result is consistent with the study of Electrin et al (2013).

Insignificant variables

In our analysis years of schooling, ownership of land and availability of transport facility have been found statistically insignificant. The value of Pseudo R2 is less than .9. The $L R$ statistics produced at $D F=10(L R=164.47)$ is significant at level of $=0.0000$. The probability level $=$ 0.0000 shows that the chances are almost zero that the results of regression model are due to random events instead of true relationship. The empirical results are shown in Table 14.

Table 14 Regression analysis of households' per capita income

\begin{tabular}{|l|l|c|}
\hline Variables & $\beta$ & Level of Significance \\
\hline Gend & -.995 & 0.174 \\
\hline M_S & -1.713 & 0.040 \\
\hline TNHM & 2.145 & 0.000 \\
\hline C_Dises & .374 & 0.531 \\
\hline
\end{tabular}




\begin{tabular}{|l|l|l|}
\hline POL & -.452 & 0.646 \\
\hline NoTLT & -.468 & 0.034 \\
\hline AOL & -.435 & 0.330 \\
\hline L_Stock & .755 & 0.353 \\
\hline Msav & -2.688 & 0.001 \\
\hline ATF & -1.0499 & 0.066 \\
\hline Constant & -3.00824 & 0.094 \\
\hline Pseudo R2 $=0.6767$ \\
\hline LR chi2 = 197.32 \\
\hline DF = 10 \\
\hline Prob> chi2 = 0.0000 \\
\hline Population = 220 \\
Incidence of poverty is dependent variable.
\end{tabular}

\section{Measuring the living standard of poor households}

We used "Ordered Logit Model" to estimate the living standard of the poor households. In our analysis living standard is assigned the values ' 1 ' to ' 3 '. The household with lower value states that there living standard is lower and the household having higher value considered as enjoying higher degree of living standard. The higher value reflects that household has higher level of standard of living and lower value depicts lower level of standard of living. The study is trying to investigate the determinants of household living standard with dependent variable: Living Standard. Years of Schooling, School going children, Number of time loan has taken, Ownership of land, Possession of Live Stock, Family Support ratio and Automobile have been taken as independent variables. The results are shown in Table 15.

Table 15 Regression analysis of households' living standard

\begin{tabular}{|l|l|c|}
\hline Variables & $\beta$ & Level of Significance \\
\hline YS & .113 & 0.010 \\
\hline SGC & -.146 & 0.149 \\
\hline NoTLT & .220 & 0.082 \\
\hline OSL & 1.834 & 0.017 \\
\hline L_Stock & .984 & 0.035 \\
\hline Msav & .540 & 0.173 \\
\hline Suportratio & .140 & 0.280 \\
\hline ATF & 2.422 & 0.000 \\
\hline Pseudo R2 & $=0.1973$ \\
\hline LR chi2(8) & $=60.48$ \\
\hline DF & $=8$ \\
\hline Prob> chi2 & $=0.0000$ \\
\hline Population & $=220$ \\
\hline
\end{tabular}

Living standard is dependent variable

\section{INTERPRETATIONS}

Years of Schooling and Living Standard: In this analysis the probability of living standard will increase as the years of schooling of household will increase.

School going children and Living Standard: The result shows that the probability of living standard will reduce as the number of school going children increases because a household having 5 to 6 children with limited income cannot afford to give education to every child.
Number of time loan taken and Living Standard: The probability of living standard will increase as the number of times loan taken are increased because household having an opportunity to take loan more than one time have the chance to improve his business and standard of living.

Ownership of Land for cultivation and Living Standard: The probability of living standard will increase as the ownership of land will increase because a household with ownership of land have an extra source of income through which he can improve the living standard of his family.

Live Stock and Living Standard: We found positive relationship between livestock and living standard. The result is statically significant. In other words the probability of living standard will increase as quantity of livestock will increase. The results match with the economic theory.

Saving and Living Standard: The result shows that the probability of living standard will increase as saving increases because household capacity to invest in business and generate more income for his family. It will increase the household standard of living. The statistical sign is significant as per economic theory..

Support ratio and Living standard: The result for support ratio for living standard is statistically insignificant. However the sign is correct. The value of Pseudo $\mathrm{R}^{2}$ is less than .9. The LR statistics produced at $\mathrm{DF}=08$ $(\mathrm{LR}=60.48)$ is significant at level of $=0.0000$. The probability level $=0.0000$ shows that the chances are almost zero that the results of regression model shows random events instead of true relationship.

\section{Conclusions}

The empirical evidence of our study proved that microfinance reduces the household poverty because seven out of eleven explanatory variables are found significant. The study revealed that gender of the household have negative relationship with household poverty as male household can earn more than female household and thus reduces the poverty. Education of the household is negatively related with household poverty because a literate person can easily record andcalculate daily transactions as compared to illiterate person. We found a negative relationship between poverty and marital status as both male and female can jointly contribute for their well-being and reduce the poverty. The study proved that as the size of household family increases the consumption level is also increase because households consume more goods and services and thus they cause the poverty to increases as family size has positive relationship with poverty. It was noted that as a household take more than one time loan it increase the chance to reduce the poverty level in his family. The result of amount of loan taken by the household is negatively related with household poverty as the amount of loan increase it helps the household to expand the business and avail better opportunities. Monthly saving 
and poverty also have significant effect on poverty because as saving level increases poverty level reduces and vice versa. It means household saving is a good indicator for poverty reduction and low income people should be encouraged to save more.

\section{Policy ReCOMmEndations}

We would like to make the following policy recommendations:-

- We recommend that loans should begiven male members of the family preferably they have more opportunities to work outside the home and they have more ability to create job opportunities..

- It is recommended that more loans should be given to those families which are large in size. Loan.

- It is recommended that preferences should begiven to those who are trust worthy and paying loans well in time.

- Authorities should give incentive to the loan taker to increase the saving through training programs

- It is recommended preferences should be given to education and skilled persons while giving loans because these persons generate more jobs.

- It is recommended that the government should give tax exemptions and other incentives to microfinance institutions to enable them to lend more money to the poor segment of the society.

- It is recommended that microfinanceinstitutions should ensure that the loan must be used for the purpose for which it was taken and utilization of loan must be monitored.

\section{REFERENCES}

Akram M. and Hussain I.(2011), :The Role of Microfinance in uplifting income level: A study of District OkaraPakistan", Interdisciplinary Journal of Contemporary Research in Business, 2:83-94

Alemu, B. A. (2006). "Microfinance and Poverty Reduction in Ethiopia". A Paper Prepared Under the Internship Program of IDRC, ESARO, Nairobi.

Awan and Maryam Islam (2014) "Relationship between Satisfaction, Attitude and Performance: A case study of MCB Bank Ltd", Journal of Marketing and Consumer Research, Vol 7.

Awan, A. (2015). Shifting Global Economic Paradigm. Asian Business Review, 4(3), 35-40.

Awan, A.G., Imran Sharif, Nasir Nadeem and Azhar Iqbal (2015) "Impact of Small \& Medium Enterprises on Poverty: A case study of Khanewal District-Pakistan" Journal of Economics and Sustainable Development, Vol.6 No.3.

Awan, A.G., Nasir Nadeem and Benish Rashid (2015) "Factors Affecting The Rural Women Labour supply in Agriculture sector: A Case study of District Rajanpur-Pakistan", Developing country study, Vol 5, No.1.

Awan, Abdul Ghafoor and Khan, Rana Ejaz Ali, The Enigma of US Productivity Slowdown: A Theoretical Analysis (April 30, 2014). American Journal of Trade and Policy, Vol. 1, No. 1, 2014; pp. 7-15. Available at SSRN: http://ssrn.com/abstract $=2601046$
Awan, Abdul Ghafoor, Brazil's Innovative Anti-Poverty and Inequality Model (August 30, 2014). American Journal of Trade and Policy, Vol. 1, No. 2, pp. 56-61, 2014. Available at SSRN: http://ssrn.com/abstract $=2632827$

Awan,A.G.,\& Usman Ali Gilani (2014) “Customer Loyalty in Financial Sector: A case study of commercial banks in Southern Punjab", International Journal of Accounting and Financial Reporting, Vol 4, No.2.

Bashir M.K, Amin A and Naeem M.K (2010), "Micro-Credit and Poverty Alleviation in Pakistan". World Applied Science Journal, 8(11): 1381-1386.

Binswagers, H.P. and Khandker, S. R. (1995). "The Impact of Formal Finance on the Rural Economy of India". The Journal of Development Studies, 32(2), 234-262.

Chaudhry I. S, and Rehman S. (2009). "The Impact of Gender Inequality in Education on Rural Poverty in Pakistan: An Empirical Analysis": European Journal of Economics, Finance and Administration Sciences, 15: 174 - 188.

Debnath S.C and Mahmud K. T (2014), “The Myth of Microcredit in Poverty Alleviation: Perspective from the Grameen Bank in Bangladesh."World Applied Science Journal 31 (6): 1025-1032.

Duong, P. and Izumida Y. (2002). "Microfinance and the Empowerment of Women: A Review of the Key Issue". http//: www.basic.wisc.edu/rf/lit/subjecttbib.thml

Ebimobowei, A., Sophia J. M. and Wisdom, S. (2012). “An Analysis of Microfinance and Poverty Reduction in Bayelsa State of Nigeria." Arabian Journal of Business and Management Review, 1(7), 38-56.

Goldberg, N. (2005). "Measuring the Impact of Microfinance: Taking Stock in what we Know." USA: Grameen Foundation.

Hulme D (1997), "Impact Assessment Methodologies for microfinance: Experience and better practice"david.hulme@man.ac.uk

Hulme D. and Mosley P. (1996). Finance against Poverty. Routlegde, London

Imoisi, Ilegbinosa A. and Opara I.G (2014), "Microfinance and its impact on Poverty Alleviation: A Case Study of some Microfinance Banks in Edo State, Nigeria." American Journal of Humanities and Social Sciences 2(1): 27-4.

Khandker R. K (2005), "Microfinance and Poverty : Evidence Using Panel Data from Bangladesh." The World Bank Economic Review, 19: 263- 286.

Khandker, S. R. (2003). "Microfinance and Poverty: Evidence Using Panel Data from Bangladesh". Retrieved from http//econ.worldbank.org

Little, E., Murduch, J. and Hashem, S. (2003). "Is Microfinance an Effective Strategy to reach the Millenium Development Goals" Jds,sagepub.com/content/25/1/85.ref.

Majoux, L. (2001). "Women Empowerment or Feminization of Debts? Towards a new Agenda for African Microfinance." Discussion Paper for One World Action Conference, United Kingdom Department for Industrial Development, London.

Mazumder M. S and Wencong L. (2013), "Micro- Credit and Poverty Reduction: A study of Mava B. (2008), Impact of Microfinance: Towards Achieving Poverty Alleviation?" Pakistan Journal of Social Sciences 5(9):876-882.

Nwigwe, C. A., Omonoma, B. T., and Okoruwa, V. O. (2012). "Microfinance and Poverty Reduction in Nigeria: A Critical Assessment." Australian Journal of Business and Management Research. 2(3), 33-40.

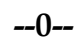

